\title{
Political participation and Citizen Innovation Laboratories: the study of CitiLab and MediaLab Prado in Spain
}

\author{
Participação política e Laboratórios de Inovação Cidadã: \\ estudo dos CitiLab e MediaLab Prado na Espanha
}

\author{
Rafael de Paula Aguiar Araújo [l] \\ Claudio Luis de Camargo Penteado [II] \\ Marcelo Burgos Pimentel dos Santos [III]
}

\begin{abstract}
This article analyzes the action of the Citizen Innovation Laboratories in the promotion of citizenship and urban management through participatory practices and use of digital technologies to develop democracy at the local level. Allied with the creative, interactive and cooperative use of ICTs, the laboratories produce collaborative practices in different projects in the cultural, social and political fields, as an alternative to traditional politics. Through an exploratory and analytical study of the experiences of Citi Lab Cornellà and MediaLab Prado, both in Spain, the article approaches some innovation practices developed in these spaces and their influences on local public policies, through the idea of shared urban management. The results indicate transformative experiences that promote the politics of the common.
\end{abstract}

Keywords: political participation; urban management; citizen innovation laboratories; democracy; common.

\section{Resumo}

Este artigo analisa os Laboratórios de Inovação Cidadã na promoção da cidadania e da gestão urbana, através de práticas participativas e de uso de tecnologias digitais, para o desenvolvimento da democracia em nível local. Aliado ao uso criativo, interativo e cooperativo das TICS, os laboratórios produzem práticas colaborativas em diferentes projetos nas áreas cultural, social e política, como alternativa à política tradicional. Por meio de um estudo exploratório e analítico das experiências do Citilab Cornellà e do Medialab Prado, ambos na Espanha, o artigo analisa algumas práticas de inovações desenvolvidas nesses espaços e suas influências nas políticas públicas locais, através da ideia de gestão urbana compartilhada. Os resultados apontam para experiências transformadoras que promovem a política do comum.

Palavras-chave: participação política; gestão urbana; laboratórios de inovação cidadã; democracia; comum. 


\section{Introduction}

In the past few years it is possible to observe the rise of multiple social practices involving experimental digital labs that use Information and Communication Technology (ICTs) for the development of tools and digital political participation devices (Gascó, 2017; Mossberger, Wu e Jimenez, 2017). For the purposes of this research, the laboratories for citizen innovation ( $\mathrm{LabCl}$ ) which operate within the concepts of common politics as well as shared urban management.

The $\mathrm{LabCl}$ promotes social experiences that have gained prominence in recent years. Differently from the laboratorial model offered by "hard sciences", these spaces are not closed for the production of specialized scientific knowledge, but the search for the development of methodologies and experimental processes open to different types of contribution. With that, they unite transdisciplinary knowledge from a wide range of scientific fields as well as social practices and traditional knowledge(s) focused on the production of social and political innovation. Different types of laboratories are being currently developed and their most common business model are startups. This article presents an exploratory and analytical study of two LabCls: CitiLab Cornellá, located in the city of Cornellá de Llobregat, in the Barcelona metropolitan region, and MediaLab Prado, situated in Madrid, both in Spain.

Spain has witnessed innovative civic engagement and participatory politics experiences since the 2008 financial crisis. In 2011, these experiences contributed to an innovative way of conducting politics focused on citizen responsibility awareness in organizational practices, observed in the camps for the "outraged movement" (15M) (Blanco et al., 2020). These practices have called attention to active citizen involvement in local level politics. This movement is also known as municipalism, for its appreciation of local government and the concept of urban common (Blanco, Gomà and Subirats, 2018), which will be further discussed later in this article.

Through the practice of these values, both selected laboratories help to illustrate alternative participatory political practices through ICTs, within a perspective that prioritizes innovation in urban environments. This new radical politics embodies distinct characteristics, like a new movement that combines traditional groups activism, alongside a strong social media penetration, creating spaces of social autonomy within the logic of the common, promoting new ways of living with principles of cooperativism (Blanco et al., 2020).

This article has as its goal the analysis of innovative LabCls, that act within the perspective of the urban common, producing emergent practices of citizenship and political participation through the development of creative ICTs use. For our methodology, this research presents an exploratory and analytical study of participation practices accomplished by the two selected Spanish laboratories, MediaLab Prado and CitiLab Cornellá. Through the description and analysis of participatory politics actions, the study identifies experiments focused on the promotion of citizenship innovation at a local level, which, in turn, contributes for the strengthening of democracy highlighting the politics of the common. 


\section{Political participation and citizen innovation}

In the environment of network society transformation (Castells, 1999), the different types of experimental laboratories are born as a more open and collaborative innovation model. With great influence of hacker ethics, the idea of DIY ${ }^{1}$ of Digital Culture and the creative use of ICTs, these laboratories allow for the development of collaborative experiments through interdisciplinary teams articulating interactive bonds between civil society, State, universities, companies, social movements and other players such as designers and hackers (Fonseca, 2017).

Political participation beyond elections has been fundamental to amplify the concept of democracy quality (Diamond and Morlino, 2005). In the past few years, it is possible to verify an increase in citizen demand for greater participatory spaces. The Spanish experiments, above all post-2008 crisis, with the $15 \mathrm{M}$ movement, in 2011, or the Outraged, are examples of how the population started locally articulating, with the express purpose of amplifying spaces of political participation (Rubio-Pueyo, 2017).

The importance of a more participative democracy has been made clear through other works, such as Fung (2009), who pointed at the need for a local community in subjects that approach the public policies that impact these groups. When the institutions, political and local, reorganize to create new opportunities to include citizens, they start exercising their collective voice and influence in local politics and decisions that affect their own lives.
As a reflection of the 2008 crisis, the Spanish population started exercising resistance to traditional political power, promoting, within the metropolis, new spaces of citizen involvement, as a way to build some social autonomy (Blanco et al., 2020). The 2015 elections in Spain became a game changer capable of exemplifying a change in the realm of traditional politics. Representatives connected to citizen platforms were elected like Barcelona en Comú, Ahora Madrid, València en Comú, Cádiz Sí Se Puede, among others, as alternatives to traditional political parties (Rubio-Pueyo, 2017). As a strategy, these platforms were incorporated to the LabCls, which started to present themselves as the possibility for the promotion of an innovative political participation, through creative ICTs.

The experimental laboratories characterize themselves for possessing an organizational structure focused on innovation, with specific protocol models, practices and actions that value openness and experimental voluntary associations, in which failures are seen as part of project development and learning (Fonseca, 2017). The laboratories take on different organizational, methodological and work models: Espaços Maker, Fab Labs, Living Labs, Government Labs and Citizen Labs. This study privileges Citizen Labs, primarily turned towards the production of citizenship innovation.

The idea of Citizen Innovation (CI) is associated with an experimental project development culture, inside the coproduction principle, through which citizen centers develop prototypes and experiments targeting the increase of citizenship. ICT use facilitates both the production and productivity of a 
collective intelligence, making experiences and knowledge exchange between citizens viable, generating solutions to different problems and social challenges, especially at a local level. In other words, the $\mathrm{Cl}$ starts from the teamwork of researchers, volunteers and the local community, incorporating distinct knowledge to solve the neighborhood's problems (Pascale and de la Fuente, 2020).

Contrary to other commercial innovations (produced by the private sector) and public policies innovation (produced by the public sector) that also operate inside the dynamic environment of Network Society (Castells, 1999), the Cl focused on "prototype" production operates with experimentation to strengthen citizenship. These processes, contrary to the government's or the market's needs, are usually constructed in a bottomup perspective (starting from the citizens) and look to answer, through collaboration, the demand formulated by its own community (Pascale and de la Fuente, 2020), inside the principles of the politics of common (Dardot and Laval, 2015a).

The CILabs disrupt the "technicist aura" of university's laboratories, sustained by "scientific truth", and proposed practices turned to the production of useful knowledge useful to the community (Savazoni, 2016). A place of encounter between different types and forms of knowledge(s), both technical and traditional, which produce political innovation for citizen practices, through collaborative processes.

In the CILabs, the technology is a central concept and is associated with politics; it does not operate with a regulation device and control similar to the existing ones in social media platforms. The technologies employed in these laboratories are open, free and reframed, in a way that can be reutilized and ressignified (ibid.) such as in the cases present in this article, which in turn can be replicated in other contexts.

The solutions and the projects proposed are presented in the form of prototypes which: (a) assume these values in the form of (concrete) material production, (b) incorporating distinct knowledge(s), and (c) need to be tested. They are "solutions always liable to be improved and allowing the incorporation of new experiences" (Pascale and de la Fuente, 2020, p. 7). The solutions and the projects developed by CILabs are thought for specific contexts, nonetheless repurposed in other spaces and scale degrees, through the reflexive processes and the original feedback prototypes.

In that way, ClLabs are configured as an agent capable of negotiating and promoting changes and innovations focused on the improvement of life in society, the formation of networks, alliances, dialogs and a new citizenship constructed from the collective, which could operate within the politics of the common.

\section{Politics of the common}

Studies about the common have been developed since the clash between Hardin and Ostrom in the 1970s, after the publication of Hardin's (1968) The tragedy of the commons in which it is defended, in broad terms, that humanity would be incapable of administering common spaces, exhausting its resources and harming most individuals in the process. To avoid such tragedy, common spaces should be 
managed by privatized initiatives. In response, Ostrom (1990) catalogued empirical studies that defy Hardin's ideas demonstrating that, yes, there is human knowledge capable of developing common spaces without depleting them, ${ }^{2}$ through mechanisms of self-management. Therefore, the idea of common space management started to be incorporated into political practices, especially after the 2008 financial crisis, in the Spanish municipalism experience.

The common also appears in the works of other authors such as Hardt and Negri (2005), who develop the concept as a political becoming in opposition to neoliberalism and a way to make possible the democracy of the multitude. In this perspective, the crowd, or multitude, allows us to encounter and develop common points for acting together. The common allows us to encounter and develop shared aspects to act conjointly. The common emerges as a practice of multitude biopolitics, through the constitution of an "open and ever-expanding" network, which connects individuals in active togetherness. This type of vision had great influences in the instituting practices of the Outraged camps, in Spain, the occupies, around the world, and can also be observed in the ICLabs.

To Dardot and Laval (2015a), the common is an organizational and action-based protocol for social institutions to oppose the privatizing logic of neoliberalism, as observed, to cite only a few examples, in Chilean student's activism for public learning institutions, and the mobilization for community management of the Bolivian water supply. The principle of the common is the direct participation both in decision processes and the management of common goods.
We adopt a perspective closer to Subirats (2016), sustaining the common good logic as a new dimension of citizenship, which starts in the most democratic way possible in the public space management of large cities today. The author argues that emergent citizenship searches for balance between individual autonomy and the non-discriminatory use of space. This search occurs through unstable and constantly negotiable counterweights, brought forward through collective construction and debate about the city at a local level.

The common good emerges as social practices (commoning) in the administration. To Subirats (ibid.), the common allows for a form of democratic city administration. Differently from the idea of deliberative democracy, the common allows for the democratic administration of cities. Differently from the idea of deliberative democracy, thought as actions previously defined for a technical body and with the citizen participation being limited to public debate, the logic of the common operates in cooperation and co-production movements in which the citizens are responsible for the manufacturing of problem solving as well as putting them to practice (Subirats and Rendueles, 2016).

The politics of the common are born out of the current necessity to search for new political participation mechanisms, before a liberal democracy scenery and the advancement of neoliberal austerity processes above all after the 2008 crisis (Blanco et al., 2020). The common rises as a real alternative to the articulation of public administration besides the population, associated with the public administration with self-management practices and actions through a territorial perspective (Blanco, Gomà and Subirats, 2018). 
The Spanish elections of 2015 point to the emergence of new political forces that broke from bipartisanship, creating municipalist encounters in different cities (Rubyo-Puyeo, 2017, p. 2). Other authors also point out that post-2015 municipalism allowed for the articulation of a political agenda guided by the right to the city, beyond forms of co-production of politics dominated by the constructions of urban commons (Blanco, Gomà and Subirats, 2018). The collective participation of citizens in the co-production of these urban policies breaks with the logic of public administration's centrality and proposes a new arrangement that aims to reactivate the bonds of territorial communities around its problems and challenges.

Therefore, rises an urban agenda informed by the construction of the common, focused on the production of the right to the city through new processes, distant from the hierarchical logics and the bureaucratic dynamic that often reserves citizens a solely passive role. It developed a new center for the birth of spaces, which allows for an interaction between daily dynamics and the formation of solidarity networks. The goals of urban management can be summarized in five strategies: (1) territorialize government: to strategize policies based on a territory and its population's specificities; (2) cocreate urban policies: the community's social fabric taking part in policies' design and implementation; (3) impulse community action: empowering communities, fomenting self-organizational models and conflict resolution; (4) opening city management to citizens; and (5) supporting social innovation: fomenting and building acceptance of initiatives and proposals co-produced by citizens themselves (ibid.).
Another fundamental aspect in this process is CITs use. Since the beginning of the internet, the idea of common good has been present. Levine (2007) proposes that the internet is born as a freeing shared good. ${ }^{3}$ An example of this common is the very use of the www (world wide web), allowed by its developer, Tim Berners-Lee. Other examples of these principles are the practices related to free softwares like the commonly used Linux as well as the Creative Commons license in direct opposition to the concept of copyright, amongst other collaborative practices such as Wikipedia (Morell, 2014).

The principle of the common, as a participative citizenship practice (Peña-Lopez, 2017), is present in these collaborative spaces connected to the digital universe, but also present in other social movements, such as Spain's Outraged and the multiple Occupies around the world. The logic of the common has been present since the self-management of occupied squares and camps to network mobilizations, fomenting insurgent citizenship practices from emerging movements in civil society, ressignifying the role of technology in its interaction with the realm of politics (Rubyo-Puyeo, 2017).

Insurgent citizenship (Holston, 2013) allows for a dialogue with new societal arrangements because it understands that this model directly dialogues with the notion of urban management and citizenship, bing informed by citizen participation and the practice of rights, collaborating to further solidify the importance of ICLabs as a place of development for new citizenship practices. These new participation uses constitute a model of political co-production, in which citizenship consists in building and generating 
the collective, not just providing opinions to pre-established subjects (Rendueles and Subirats, 2016).

In the past few years, it is undeniable that ICTs have conducted a deeply meaningful political role in democratic life (Dahlgren, 2015). The internet acts as a vic space in which online politics grows inninterruptly, mainly due to the possibility for mobilization and amplification of civic engagement, allowing new involvements and cultural activities, not just during electoral periods, but in other moments, such as political actions organized through ICT use (Castells, 2017).

In the current moment of severe crisis in traditional political institutions, democracy needs to be seen as more republican and less elitist (Dahlgren, 2015). Because of said necessity, many institutions have been developing experiences through ICT use for the creation of more interactive political processes, with further transparency and accountability on the part of public management, as demonstrated by Almada et al's 2019 digital democracy studies.

\section{LabIC}

The Citizen Labs (LabIC) present themselves as alternatives to an innovative form of political participation through ICT's. For that, the development of an open innovation ecosystem, beyond the efforts of common citizens alone, is created and incentivized through joint ventures between public and innovation players, interested in participating and building solutions to cities' problems. These practices emerge as political alternatives, through which citizens have an active role in the identification, creation and planning of solutions to problems present at a local level, which is denominated coproduction of public policy (Subirats, 2015).

Other experimental digital laboratories work with ICT use in the promotion of tools, devices and platforms for political participation in a perspective of social innovation found within a technological solution. Despite that, it needs to be remarked that LabICs operate inside the conception of citizen innovation, through which projects and prototypes are developed, created and dedicated to producing a social impact. Their innovations are a result of collective processes that value local (territorial) specificities, considering an inclusive perspective that actively values listening, submersion and participation (Freire, 2017), in which people, not technologies, are protagonists.

With the purpose to illustrate emerging participation practices of common politics promoted by Citizen Labs, presenting two Studies about ICTs by Spanish laboratories. The first is CitiLab, located in the city of Cornellá de Llobregat, in Barcelona's metropolitan region, and the second, MediaLab Prado (MLP), situated in Madrid. Beyond an organizational description and work structure of the selected LabIC, we present an identification of knowledge networks and collaboration through which laboratories participate. This process is important, because, as previously pointed out, the practices within those laboratories can be replicated in other localities. By allowing for the tracking of other agents and collaboration networks, the sharing and diffusion of knowledge and resources, helps to consolidate new urban management practices. 


\section{CitiLab Cornellà}

CitiLab ${ }^{4}$ is situated in Cornellá de Llobregat, in Barcelona's Metropolitan Region; it's a citizenship-focused social and digital laboratory inside a territorial perspective to promote a "society of knowledge" at a local level. For that, collaborative learning processes turned to innovating and strengthening community bonds. It's current base was inaugurated in November 2007, in the factory of Can Suris. This factory, built in 1897, was renovated to the 21st Century by the Cornellà prefecture, from 2003 to 2007, in consonance with new inclusive efforts by the city, a theme present in Spain since the 1992 Summer Olympics (Rubyo-Puyeo, 2017).

Citilab attempts to create interactions between companies, entrepreneurs and public officials. It is composed of an administrative council presided by Cornellà de Llobregat's mayor and representatives of the Autonomous community of Catalonia, Catalonia's research and innovation foundation as well as the Polytechnic University of Catalonia. As it can be observed, it includes institutional actors belonging to diverse social, political, academic and market spheres, demonstrating its new possibilities for local urban management.

According to the mission statement posted to their website, the activities accomplished are focused on the development of technological innovation through the relationship between society, art, science and the ICTs themselves. Citilab sees in digital culture a possibility for the creative use of technology in favor of local and regional use through training, programs and projects. Its activities operate within the $3 \mathrm{H}$ methodology: discovering innovative minds (Head), establishing trust (Heart) and learning to work collaboratively (Hands on). The activities are articulated within values like: experiences, methodologies, tools and knowledge, having as expected results the production of community, competences, projects and Citizen values.

Citilab is organized in four laboratories (projects): (1) Col•laboratori, operated in the sector of incentive to cultural initiatives as well as social and technological innovation networks; (2) EduLab, acts in the innovation learning sector; (3) LaborLab, develops co-creation and entrepreneurship actions in a sustainable environment, focused on generating professional activities and income; and (4) ThinkLab, creates activities focused on the reflection, debate, promotion and education of both partners and users.

The actions, focused on innovation, utilize technologies, especially ICTs, as a way to promote the collaboration and direct involvement of citizens in the process. CitiLab has as a work methodology the actions produced in Living Labs which prioritize the openness of systems and the sharing of citizen innovation methods, as an openly political stand. Living Labs create connections between public administration, companies, university research groups and citizen project development, inside the four-point helix model, which integrates these four actors. In this model, experiences with experimental characteristics are placed front and center, incentivising the active citizen involvement as co-creator of both alternatives and solutions. With that a live laboratorial mentality of interaction between participants and territories is developed. 
Having adaptations of the Citizen Driven Innovation Guide 5 as a starting point, CitiLab also develops actions focused on Cornellà de Llobregat's municipality and the greater Barcelona region. For that, design thinking is utilized to increase computational thinking and further advancing user-centric co-creation. Citilab isn't just an experimental public laboratory, but a mixture of training center, research, as well as social and business incubator, therefore differentiating it from MediaLab Prado.

Amongst the many Citilab projects, we highlight, for the purposes of this analysis, Col. laboratori, which is focused on potentializing CITLabs through the identification of innovation agents and their motivations. The project incentivises the formation of interest groups and communities to experiment new participation models, organization and government, promoting co-responsibility with said agents through the creation of an innovation culture committed to social and economic development. It features users, citizens, communities, students, public offices, market leaders and universities. On Table 1, Col.laboratori's actions are presented and systematized.

As it can be observed on Table 1, the Col.laboratori project is representative of CitiLab. It proposes from internal activities to the furthering of engagement and searches for solutions within the metropolitan region. The project has attempted to act in sportive and educational actions. With the sports community, the Col.laboratori acts with the Cornellà Sport's department, initially in the identification, connection and involvement of community agents. Through co-creation processes, the capacitation of agents was conducted alongside the development of communication and transmedia communication projects for the promotion of sports' programs in the city.

Table 1 - Col.laboratori projects

\begin{tabular}{|l|l|l|}
\hline \multicolumn{1}{|c|}{ Sector } & \multicolumn{1}{|c|}{ Projects } & \multicolumn{1}{c|}{ Description } \\
\hline $\begin{array}{l}\text { Internal } \\
\text { (to CitiLab) }\end{array}$ & $\begin{array}{l}\text { OpenSurf } \\
\text { Sucom (community support) } \\
\text { Sues (student support) }\end{array}$ & $\begin{array}{l}\text { Projects focused on the development of CitiLab } \\
\text { users' talents and ideas }\end{array}$ \\
\hline External & Collaborative Economy Projects & $\begin{array}{l}\text { Collaboration with the Network for social and } \\
\text { Collaborative Innovation (XISC) to promote Baix } \\
\text { Llobregat's collaborative economy }\end{array}$ \\
\hline Regional & $\begin{array}{l}\text { The Baix Llobregat county's } \\
\text { Regional Specialization and } \\
\text { Competitiveness Project (PECT) }\end{array}$ & $\begin{array}{l}\text { Project focused on working towards the training } \\
\text { of local innovation agents with the goal of } \\
\text { strengthening the region's citizenship labs }\end{array}$ \\
\hline Metropolitan & AreaLab & $\begin{array}{l}\text { Formation of a metropolitan laboratory Network in } \\
\text { the region's 36 municipalities, acting as open spaces } \\
\text { for the territory's social and political innovation }\end{array}$ \\
\hline
\end{tabular}

Source: created by the authors of the present article. 
In the educational realm, projects inspired by Bibliolabs ${ }^{6}$ were created, which established a strategic alliance with the city's libraries. This collaborative process occurred in partnership with the Cornellà and Barcelona prefectures, with the laboratory acting as the local and regional axis. The project utilizes innovative, creative and collaborative methodologies to transform the public libraries' uses, services and functionalities. The idea is to amplify the conception of these digital era spaces, transforming in assistance and citizen innovation centers.

Another political participation field promoted by CitiLab is the A Prop Te $u^{7}$ project, an urban management platform created in the interaction between municipal and citizen management, the search to generate actions committed to the improvement of public spaces through open network models. The A Prop Teu attempts to promote a closer relationship between municipal management organs and the co-responsibility for solving the city's daily problems and challenges. The project has a platform that promotes the open management of actions and themes of interest to citizens. The communication, in its turn, occurs through social media, like Facebook and Twitter, and allows to detect topics of collective interest in relation to the common space, creating connections between citizens and public officials, auxiliating local urban management.

Citilab is a member of the European Network of Living Labs (ENoLL), which, beyond Europe, is present in multiple laboratories across continents. ENoLL united 154 laboratories, spread throughout 36 countries, acting in a diverse range of areas, such as: health and well-being; smart cities, smart cities and regions; culture and creativity; energy; mobility; inclusion; social innovation; government; education. This highlights the interaction aspects between civic community and political actors in the joint development of urban management and the challenge of local problems.

\section{MediaLab Prado}

The MediaLab Prado (MLP), ${ }^{8}$ an experience connected to Madrid's Museo Nacional del Prado, attempts to promote social change through the development of tools, services and processes focused on empowering citizens, integrating artistic, social and political elements. MLP was founded by a group of cultural activities and places itself as an alternative to the type of neoliberal cultural politics implemented in Madrid during the 2000's which attend mostly to interest of the tourism industry (Rubio-Pueyo, 2017). Inspired by transdisciplinary approaches and hacker philosophy, MLP has as its main axis the promotion of local projects, betting on culture as a source of development and innovation promotion, through participative and creative processes (Criado Valladares, 2016).

MLP is a Madrid's municipality program which functions as a space for the production of open and collaborative culture, as presented in its website. ${ }^{9}$ It functions through (1) laboratories which, despite thematic, produce integral works; (2) work groups (WG); and (3) open calls for the production of projects, collaborative investigations and learning communities in multiple themes. 
It is possible to verify that MLP has, as its main concerns, the encouragement and the development of the collaborative work, the application of projects and experiments as well as the establishment of a critical vision on technologies, valuing free cultural principles (free hardware and software use as well as open code) and free access to different types and forms of knowledge. All online contents are made public in free licenses (Creative Commons), as a way to allow others to replicate and access, recognizing knowledge as a common good which is constructed in a collaborative and collective manner.

The open and free participation in work groups. There is also the possibility to submit to open calls for the development of collective projects. Online participation happens through the community: Comunidad MediaLab Prado. In the platform, users can access information for projects developed or currently being developed by MLP.

MLP is structured in six laboratories: (1) DataLab, open data laboratories; (2) PrototipaLab, creative prototype laboratory; (3) ParticipaLab, collective intelligence laboratory for democratic participation (analized below); (4) InCiLab, citizen innovation laboratory; (5) CiCILab, laboratory for citizenship-driven science; and (6) AVLab, audio/visual experimentation laboratory. All those MLP laboratories are focused on citizen innovation and possess projects that dialogue with the principle of the common.

To evaluate political participation practices, we highlight programs and projects developed by ParticipaLab, directed towards citizenship innovation programs dedicated to democratic and political participation in local urban management, but also possible to be verified in other participative projects within other MLP labs.

ParticipaLab ${ }^{10}$ is an axis within MLP focused on the study, development and practice of political participation processes with emphasis in the solution and intervention of urban problems. To accomplish this goal, it promotes a combination of in-person and digital spaces, amplifying the experience of direct and deliberative democracy. ParticipaLab is responsible for the evaluation of direct participative systems as well as deliberative processes in which decisionmaking is conducted through digital tools.

To accomplish such activities, ParticipaLab acts in different partnerships, such as the one with Gobierno abierto del Ayuntamiento de Madrid and the Decide Madrid ${ }^{11}$ platform, a digital channel for citizen participation in the municipality. This platform allows for actions through consultations, proposal presentation and political debate, framing it as a participatory experience constructed within principles of the common and through the use of open and free tools, serving as a model for the Decidim platform adopted by the city of Barcelona (Penteado and Souza, 2019).

The replication of experiences in other platforms and municipalities denotes the exchange of knowledge and practices considered to have positive effects, and therefore, replicable to other communities in the region, demonstrating democratic CIT use in congruence with the main liberal and collaborative principles of the internet in its infancy. On Table 2, the main ParticipaLab programs and projects have been described and systematized. 
Table 2 - Participa.Lab Projects

\begin{tabular}{|c|c|c|}
\hline Programs & Projects & Description \\
\hline $\begin{array}{l}\text { Inteligencia colectiva } \\
\text { para la democracia }\end{array}$ & $\begin{array}{l}\text { - Citizen participation planning hub } \\
\text { - GANA Municipalidades } \\
\text { - Holopolis: prototipando la democracia del futuro } \\
\text { - Indicadores de calidad democrática (democratic quality } \\
\text { indicators) } \\
\text { - Expandiendo la funcionalidad Consul para presupuestos } \\
\text { participativos } \\
\text { - Noticias fiables para la mejora democrática (Better news) } \\
\text { - MingaLab: democracia comunitaria para futuros en } \\
\text { común } \\
\text { - Levanta la Mano: Metodología de participación ciudadana } \\
\text { para niños, niñas y adolescentes } \\
\text { - Ciudad.Decide } \\
\text { - Consul Going World Wide } \\
\text { - Wikium } \\
\text { - Hybrid Democracy } \\
\text { - Coder Dojo } \\
\text { - Futuro Digitales } \\
\text { - Futuro Digitales }\end{array}$ & $\begin{array}{l}\text { Collective work methodologies } \\
\text { through which, in a } 15 \text { day period, } 10 \\
\text { multidisciplinary teams participate } \\
\text { in workshops for prototype creation } \\
\text { towards collective intelligence, improving } \\
\text { democracy and commitment to citizens }\end{array}$ \\
\hline $\begin{array}{l}\text { Comunidades para } \\
\text { acción colectiva }\end{array}$ & $\begin{array}{l}\text { - Formación e investigación sobre las relaciones ciudadanas } \\
\text { con Decide Madrid } \\
\text { - Rutas para radicalidad democrática } \\
\text { - la cocTELLera } \\
\text { - Comunidades Propositivas }\end{array}$ & $\begin{array}{l}\text { Program focused on the discussion, } \\
\text { analysis and collective construction of } \\
\text { alternatives to the activation of citizen } \\
\text { political participation }\end{array}$ \\
\hline Culturas de la movilidad & $\begin{array}{l}\text { - Mejoras TXMAD } \\
\text { - Sensortaxi } \\
\text { - Sistema de valorizatión del servicio en el taxi } \\
\text { - Auto-documenta } \\
\text { - Paradas de taxi } \\
\text { - Central receptora de alarmas e IoT } \\
\text { - Taxi } 5.0 \\
\text { - Taxi Excelente, por las buenas prácticas } \\
\text { - Mujer y taxi }\end{array}$ & $\begin{array}{l}\text { InCiLab's joint program alongside } \\
\text { ParticipaLab centered on the discussion } \\
\text { of collective and collaborative alternatives } \\
\text { in favor of the incentive to a mobility } \\
\text { culture }\end{array}$ \\
\hline $\begin{array}{l}\text { Estudio y } \\
\text { experimentación con } \\
\text { Decide Madrid }\end{array}$ & $\begin{array}{l}\text { - \#CodingMadrid } \\
\text { - Ciudad.Decide }\end{array}$ & $\begin{array}{l}\text { This program places all citizen } \\
\text { participation projects into groups in } \\
\text { a transversal strategy intended to } \\
\text { collaborate and deliberate processes }\end{array}$ \\
\hline $\begin{array}{l}\text { Democracia, } \\
\text { deliberación y sorteo }\end{array}$ & $\begin{array}{l}\text { - Observatorio de la ciudad } \\
\text { - G1000 Madrid } \\
\text { - Igualdade x sorteo } \\
\text { - Hybrid Democracy }\end{array}$ & $\begin{array}{l}\text { Citizen participation experiment through } \\
\text { a randomly selected citizen sample } \\
\text { invited to deliberate Madrid's problems }\end{array}$ \\
\hline Ciudades democráticas & $\begin{array}{l}\text { - Conferencia Internacional de Ciudades Democráticas } \\
\text { (2017 }\end{array}$ & $\begin{array}{l}\text { Citizen participation technological } \\
\text { event, with workshops, conferences and } \\
\text { hackathons in } 2017 \text { in Madrid }\end{array}$ \\
\hline
\end{tabular}

Source: Created by the authors of the present article. 
ParticipaLab is one of MLP's most active laboratories. Despite ICTs occupying a central role to the majority of programs and projects developed in laboratories, the focus is not in the use of these instruments, as argued by Marcos García, ${ }^{12}$ MediaLab Prado artistic director. To him, technologies function mainly as "inspiration" and "support" to projects and "the main goal is to find ways to unite and work in common projects".

Digital technologies are important because they allow for the creation of new gadgets to be appropriated by Madrid citizens, like in projects such as the Cultura de la Mobilidad programs. The interaction is also present amongst participants of the Inteligencia Colectiva para la Democracia projects. Another example of citizen participation in city management is in the use of the Decide Madrid platform. MLP is unique not only for its creative ICT use, but also for its integration and operation within the logic of the common.

The Decide Madrid platform is structured in open software and free consultation named Consul. ${ }^{13}$ This experience is a learning and articulation space with other participative MediaLab Prado projects. The Consul software itself was developed to promote citizen participation and is being used in other cities like Barcelona, Paris and Rome, Because it is an open source software, it can be adapted to each locality's needs perfecting its functionalities. Consul's main functions are: proposal submission to the improvement of the city; voting online; developing legislation in a collaborative manner; participative digital budget; advanced online participation projects, as well as debates and discussions proposed by users.
Another associated project is \#CodingMadrid, which consists of a call for programmers to participate in the Consul software development team. These encounters form a space to discuss problems and proposals for the platform's development through collaborative practices. The codes are available for public consultation and access.

The Decide Madrid platform began in 2015 and, ever since, it called researcher's attention to the capacity of citizen participation, with technological innovation (Cantador et al., 2017), with a device to the accomplishment of participative budgets, like the adoption of the common as a participative principle (Penteado and Souza, 2019). The platform has a pilot-project turned to its territorialization entitled Ciudad.Decide, which has as its main goal to increase territory-based participation, promoting in-person meetings for the elaboration of urban management proposals. This pilot is being developed in the Fuencarral territory in integration with other projects in local public politics.

MediaLab Prado's acting network was developed in Madrid, but amplified to the international field. Being a laboratory associated with municipal management, its local network attempts to connect to the Spanish capital's neighborhoods, acting within the perspective of territory use. Acting in association and partnership with other administrative areas for the development of transversal projects like the Experimenta Distrito, developed in the Puentes Vallecas, Fuencarral, Moratalaz and Retiro neighborhoods.

In the international field, contrary to CitiLab, MLP does not participate in any specific network, but interacts with experiences 
and citizen innovation developed in other regions of the world. For example, remarking the partnership between CILabs around the world, especially with the Ibero-American Secretary-General and the network of IberoAmerican Citizen innovation, composed by 20 laboratories.

\section{Final remarks}

From the highlighted examples, it is possible to identify the CILabs as agents promoting citizen innovation through the development of political participation projects involving CIT use. The CILabs are organized in a different political, creation making and acting logic, searching for a new horizon, a new political becoming, oriented by the politics of the common.

The co-production proposal common to all projects developed by CILabs present themselves as an alternative to the individualized and atomized participation common in e-participation experiences, because they utilize said technologies for the promotion of a collective practice in which each citizen is co-responsible for problem solving and managing the city's shared spaces and goods. Through interactions with a crowd, the CILabs try to resignify the conception of technology as an ecosystem of networks and data, which can be reutilized by public institutions, helping in local needs, perfecting its services for those who use it. Doing that through citizen's democratic participation and public data proprietorship (Rubio-Pueyo, 2017). In this new perspective, interactions and shared virtual knowledge are unified with concrete urban needs.
The CILabs have developed mechanisms of assistance to decision-making processes in the local and regional development, through their actions and the use of technological innovation. Consequently, the experiences have allowed for the construction and strengthening of a more substantive and less formal democracy. The laboratories' projects incentivise citizen participation from the actuality of local reality and collaborative work. In the CILabs studied, the technology seems not solely an innovation and participation tool, but also a mediation mechanism for the encounter between interested people in developing projects for the improvement of the city. Therefore, uniting digital and in-person experiences, online and offline.

Furthermore, the production of knowledge and practices are made available based on free licenses (Creative Commons), to be replicated and accessible to other collectives and other municipalities. Despite the MLP being associated with both a museum and Madrid Municipality's cultural program, its political actions and technologies are central mechanisms to political participation in the Spanish capital. CityLab acts mainly in the articulation of innovation agents in Barcelona's metropolitan region, with a focus on partnerships for citizen innovation such as, for example, in the areas of education and sports. In both cases, it is possible to observe the cooperation between citizens and government in qualification of public policies as well as the idea of knowledge built collectively and collaboratively, incited by the logic of the common.

Recently, the Madrid prefecture has hosted a series of maneuvers with the goal to deactivate MediaLab Prado, one 
of the laboratories analysed here, and in its place establish a municipal museum for contemporary art. ${ }^{14}$ The case brings back the alert for the way in which projects strengthen citizen participation promoting citizen responses to changes in their local area are often discontinued. This occurs due to the lack of understanding around the importance of a citizen to organically impulse citizen action for innovation, considering the population in an active and propositional fashion. Shutting these centers down reveals a fragil perspective of democracy and its holistic reaches and functions, reflecting the existence of management openly against participative practices and innovation, opting for placing citizens in a passive role within representative democracy.

This traditional model of representation, in which political participation is restricted to voting, does not answer the needs created by the current zeitgeist defined by technical-scientific-informational development. The high rate of change faced by metropolises demands new methods of participation, allowing citizens to actively appropriate innovation, organizing themselves in networks and in a collaborative fashion, finding creative solutions to different urban problems.

The cases studied highlight the advantages of experiences that apply technology to the construction and diffusion of common knowledge, a model still rarely developed in the Global South. Sharing knowledge and replicating good public policies practices find, in innovation laboratories, a fertile camp for the transformation of public spaces and the proposition of new social transformation goals, especially within a local level. In contrast, Brazilian innovation laboratories generally follow a market-driven startup logic, with little to know citizen participation. The analysed examples can serve as a parameter for the incentive of new social entrepreneurship initiatives, capable of synergically enjoying individual potential and promoting civic consciousness through collaborative practices.

The participation projects presented in the research, through ICTs use, are appropriate and compatible to the five strategies of the urban common politics' agenda (Blanco, Gomà and Subirats, 2018), namely: (1) developing projects, programs and prototypes that work inside a territorial dimension; (2) producing political coproduction projects created by participants of both laboratories; (3) promoting community and political actions; (4) creating common spaces for urban self management; and (5) providing support for social innovation and citizenship initiatives developed by its participants.

The politics of the common and CILabs rise as an important practice and experience to develop political alternatives to be incorporated in municipalities' urban management and regional areas. This way of thinking and producing local civil participation qualifies citizenship, despite multiple limitations of local action's power. It is possible to witness improvements in public administration, inside a context of internet use and amplification of citizen participation. Experiments with the laboratories here contemplated contribute to the creative and sustainable technology use and diminish the abysmal civic segregation, fruit of the individualism characteristic of life in a metropolis. 


\section{[I] https://orcid.org/0000-0002-7632-6053}

Pontifícia Universidade Católica de São Paulo, Social Sciences College, Graduate Program in Social Sciences. São Paulo, SP/Brasil.

rafael.araujo1977@gmail.com

\section{[II] https://orcid.org/0000-0002-8279-3643}

Universidade Federal do ABC, Sciences and Humanities BSc, Graduate program in Human and Social Sciences. São Bernardo do Campo, SP/Brazil.

claudio.penteado@ufabc.edu.br

\section{[III] https://orcid.org/0000-0001-7075-6258}

Universidade Federal da Paraíba, Social Sciences department, Graduate program in political Science and international relations \& Graduate program in sociology. João Pessoa, PB/Brazil.

marceloburgos@cchla.ufpb.br

Translation: this article was translated from Portuguese to English by Sailboat Writing, a New York based media+education agency. For more information, contact: admin@sailboatwriting.com

\section{Notes}

(1) Acronym for: Do-It-Yourself - building, modifying, or repairing things by oneself without the direct aid of insider expertise.

(2) The task started by Ostrom began and continues to this day through the International Association for the Studies of the Commons (Iasc) - a work that has earned him the Nobel Prize in economics.

(3) Although it is important to notice that today the internet is mostly under the control of large corporations (Gafam - Google, Apple, Facebook, Amazon and Microsoft).

(4) In 2013, CitiLab was cited as one of the greatest innovation practices by the European Commission (Hurtado, 2013). For more information, see: <https://www.citilab.eu>.

(5) Guide developed by the European Living Labs Networks and the World Bank.

(6) For more details, see: <https://www.citilab.eu/bibliolab/>.

(7) For more details, see: <https://www.citilab.eu/projecte/a-prop-teu-programa-participaciociutadana/>.

(8) For more details, see: <https://www.medialab-prado.es>.

(9) For more details, see: https://www.medialab-prado.es/. 
(10) For more details, see: <https://www.medialab-prado.es/laboratorios/participalab>.

(11) For more details, see: <https://decide.madrid.es>.

(12) Interview given through video conference on 8/25/2019.

(13) For more information about the Consul project and to access its codes, see: : http://consulproject. org/en/. Access on: 1/27/2020.

(14) Cf. artigo de Lafuente (2021).

\section{References}

ALMADA, M. P.; CARREIRO, R.; BARROS, S. R.; DA SILVA GOMES, W. (2019). Democracia digital no Brasil. MATRIZes, v. 13, n. 3, pp. 161-181.

BLANCO, I.; GOMÀ, R.; SUBIRATS, J. (2018). El nuevo municipalismo: derecho a la ciudad y comunes urbanos. Gestión y Análisis de Políticas Públicas, v. 20, pp. 14-28.

BLANCO, I.; SALAZAR, Y.; BIANCHI, I. (2020). Urban governance and political change under a radical left government: the case of Barcelona. Journal of Urban Affairs, v. 42, n. 1, pp. 18-38.

CANTAdoR, I.; Bellogín, A.; CORTÉS-Cediel, M. E.; GIL, O. (2017, August). Personalized recommendations in e-participation: Offline experiments for the 'Decide Madrid' platform. In: Proceedings of the International Workshop on Recommender Systems for Citizens (pp. 1-6). Como/Italy. DOI: https://doi.org/10.1145/3127325.3127330.

CASTELLS, M. (1999). A sociedade em rede. A era da Informação: economia, sociedade e cultura, v. 1. São Paulo, Paz e Terra.

(2017). Redes de indignação e esperança: movimentos sociais na era da internet. Rio de Janeiro, Zahar.

(2018). Ruptura: a crise da democracia liberal. São Paulo, Companhia das Letras.

CRIADO VALLADARES, M. E. (2016). Los laboratorios ciudadanos. Un estudio de caso: el MedialabPrado y su impacto en el ámbito local. Disponível em: http://openaccess.uoc.edu/webapps/o2/ handle/10609/61345. Acesso em: 20 abr 2020.

DAHLGREN, P. (2015). "The internet as a civic space". In: COLEMAN, S.; FREELON, D. Handbook of digital politics. Cheltenham/United Kingdon, Edward Elgar Publishing.

DARDOT, P.; LAVAL, C. (2015a). Commun: essai sur la révolution au XXle siècle. Paris, La Découverte.

(2015b). Propriedade, apropriação social e instituição do comum. Tempo Social, v. 27, n. 1, pp. 261-273.

DIAMOND, L.; MORLINO, L. (eds.). (2005). Assessing the quality of democracy. Baltimore/USA, JHU Press.

FONSECA, F. (2017). Dos laboratórios experimentais à inovação cidadã | From experimental laboratories to citizen innovation. Liinc em Revista, v. 13, n. 1, pp. 272-279. 
FREIRE, J. (2017). Inovação social vs inovação cidadã. In: Innovación Ciudadana.Org, Projeto da Secretaria-Geral Ibero-americana. Disponível em: https://www.innovacionciudadana.org/pt-pt/ inovacao-social-vs-inovacao-cidada/. Acesso em: 24 jan 2020.

FUNG, A. (2009). Empowered participation: reinventing urban democracy. Princeton University Press.

GASCÓ, M. (2017). Living labs: Implementing open innovation in the public sector. Government Information Quarterly, v. 34, n. 1, pp. 90-98.

HARDIN, G. (1968). The tragedy of commons. Science, v. 162, n. 3859, pp. 1243-1248.

HARDT, M.; NEGRI, A. (2005). Multidão. Rio de Janeiro, Record.

HOLSTON, J. (2013). Cidadania insurgente: disjunções da democracia e da modernidade no Brasil. São Paulo, Companhia das Letras.

HURTADO, A. S. (2013). Tres problemas sobre los laboratorios ciudadanos: una mirada desde Europa. CTS: Revista iberoamericana de ciencia, tecnología y sociedad, v. 8, n. 23, pp. 283-298.

LAFUENTE, A. (2021). O que se pode perder com o MediaLab-Prado. In: Outras Palavras (website de jornalismo digital). Texto publicado em 19/3/2021 e atualizado em 20/3/2021. Disponível em: https://outraspalavras.net/movimentoserebeldias/o-que-se-pode-perder-com-o-labmediaprado/?fbclid=IwAR08AHAUyxnHArmgefmqoBDtAS01NsOPaxNJ0iY5Zy1HRUFZmwGE_ItiLhE. Acesso em: 19 abr 2021.

LEVINE, P. (2007). Collective action, civic engagement, and the knowledge commons. In: HESS, C.; OSTROM, E. (eds.) Understanding knowledge as a commons. Cambridge/Massachusetts, MIT Press.

MORELL, M. F. (2014). "8 Governance of Online Creation Communities for the Building of Digital Commons". In: FRISCHAMM, B; MADISON, M.; STRANDBURG, K. (eds.). Governing knowledge commons. Oxford, Oxford University Press.

MOSSBERGER, K.; WU, Y.; JIMENEZ, B. S. (2017). "Developments and challenges in e-participation in major US cities". In: CHEN, Y.; AHN, M. (eds.). Routledge Handbook on Information Technology in Government. Nova York, Routledge.

OSTROM, E. (1990). Governing the commons: the evolution of institutions for collective action. Cambridge University Press.

PASCALE, P.; DE LA FUENTE, J. R. (2020). Prototipando las instituciones del futuro: el caso de los laboratorios de innovación ciudadana (Labic). Revista Iberoamericana de Estudios de Desarrollo= Iberoamerican Journal of Development Studies, v. 9, n. 1, pp. 6-27.

PEÑA-LÓPEZ, I. (2017). Citizen participation and the rise of the Open Source City in Spain. Research Brief: IT for change. Disponível em: https://opendocs.ids.ac.uk/opendocs/bitstream/ handle/20.500.12413/13006/Research-Brief-Spain.pdf. Acesso em: 20 fev 2020.

PENTEADO, C.; SOUZA, P. (2019). E-participação e deliberação "comum": análise das plataformas “Decide Madrid” e "Decidim Barcelona”. COMPOLÍTICA 8. Paper. Brasília, UnB, maio.

RENDUELES, C.; SUBIRATS, J. (2016). Los (bienes) comunes:¿ oportunidad o espejismo?. Barcelona, Icaria.

RUBIO-PUEYO, V. (2017). Municipalismo en España. Nova York, Rosa Luxemburg Stiftung. 
SAVAZONI, R. (2016). Laboratórios Cidadãos em rede e como rede. Disponível em: http://www. articaonline.com/wp-content/uploads/2016/09/Gcultural2016-Mesa1-Laboratoriosciudadanos.pdf. Acesso em: 23 abr 2019.

SERIDÓRIO, D. F.; LUVIZOTTO, C. K. (2017). Internet como espaço de deliberação e participação política. Comunicação \& Sociedade, v. 39, n. 3, pp. 79-110.

SUBIRATS, J. (2015). "Políticas urbanas e innovación social. Entre la coproducción y la nueva institucionalidad. Criterios de significatividad." In: SUBIRATS, J; BERNARDOS, A. (eds.). Innovación social y políticas urbanas en España. Barcelona, Icaria Editorial.

(2016). “Explorando el espacio público como bien común. Debates conceptuales y de gobierno en la ciudad fragmentada”. In: RAMIREZ, K. (ed.). La reinvención del espacio público en la ciudad fragmentada. Ciudad de México, Unam, Instituto de Investigaciones Sociales.

Received: November 14, 2020

Approved: March 17, 2021 
